\title{
Chagas Disease: From Discovery to a Worldwide Health Problem
}

\begin{abstract}
Kárita Cláudia Freitas Lidani ${ }^{1}$, Fabiana Antunes Andrade ${ }^{1}$, Lorena Bavia ${ }^{1}$, Flávia Silva Damasceno ${ }^{2}$, Marcia Holsbach Beltrame ${ }^{3}$, lara J. Messias-Reason ${ }^{1}$ and Thaisa Lucas Sandri ${ }^{1,4 *}$

'Laboratory of Molecular Immunopathology, Clinical Hospital, Federal University of Paraná, Curitiba, Brazil, ${ }^{2}$ Laboratory of Biochemistry of Tryps-LaBTryps, Department of Parasitology, Institute for Biomedical Sciences, University of São Paulo, São Paulo, Brazil, ${ }^{3}$ Laboratory of Human Molecular Genetics, Department of Genetics, Federal University of Paraná, Curitiba, Brazil, ${ }^{4}$ Institute of Tropical Medicine, University of Tübingen, Tübingen, Germany
\end{abstract}

Carlos Chagas discovered American trypanosomiasis, also named Chagas disease (CD) in his honor, just over a century ago. He described the clinical aspects of the disease, characterized by its etiological agent (Trypanosoma cruzi) and identified its insect vector. Initially, CD occurred only in Latin America and was considered a silent and poorly visible disease. More recently, CD became a neglected worldwide disease with a high morbimortality rate and substantial social impact, emerging as a significant public health threat. In this context, it is crucial to better understand better the epidemiological scenarios of CD and its transmission dynamics, involving people infected and at risk of infection, diversity of the parasite, vector species, and T. cruzi reservoirs. Although efforts have been made by endemic and non-endemic countries to control, treat, and interrupt disease transmission, the cure or complete eradication of CD are still topics of great concern and require global attention. Considering the current scenario of $\mathrm{CD}$, also affecting non-endemic places such as Canada, USA, Europe, Australia, and Japan, in this review we aim to describe the spread of CD cases worldwide since its discovery until it has become a global public health concern.

Keywords: Chagas disease, epidemiology, Trypanosoma cruzi, Chagas cardiomyopathy, neglected disease

\section{INTRODUCTION}

Chagas disease (CD) is an anthropozoonosis caused by the protozoan parasite Trypanosoma cruzi, that affects about 6-8 million people worldwide (1) and causes approximately 50,000 deaths per year. Another 65-100 million people are living in areas at risk for infection worldwide (2-4). Even though over a century has passed since its discovery, $\mathrm{CD}$ remains one of the leading public health problems for most Latin American countries. In recent decades, $\mathrm{CD}$ has also been a concern for non-endemic places such as Canada, USA, Europe, Australia and Japan due to the constant migration of individuals from endemic areas (5). In this situation, the transmission occurs mainly through blood transfusion, organ transplantation or vertical transmission from mother to child.

The infection has two successive phases. The acute phase is characterized by a high parasitemia, usually asymptomatic or oligosymptomatic with fever, anorexia, and tachycardia (6). These manifestations disappear spontaneously in $90 \%$ of the cases, and possibly $60-70 \%$ of infected individuals will never develop signs or symptoms related to $\mathrm{CD}$, characterizing the indeterminate form. The remaining patients (30-40\%) may progress to the chronic phase with neurological, 
cardiac, digestive (megacolon or megaesophagus), or cardiodigestive clinical complaints (7). Chronic chagasic cardiomyopathy (CCC) is the most serious manifestation of the disease, affecting one-third of individuals with positive serology (8), and in severe cases, the only treatment option is heart transplantation. Despite efforts to understand the parasitic tropism for certain tissues, such as the heart, the factors involved in the clinical progression from indeterminate to symptomatic forms are still unknown.

Chronic CD is considered a disabling disease responsible for the most significant morbidity and mortality among parasitic diseases (9), leading to a global expenditure of USD $\$ 627.5$ million per year in health care costs (10). The estimated cost per patient at the early stages of the disease is $\$ 200$, but in the chronic symptomatic form, this value can reach 4,000 to 6,000 dollars (11). Considering that the current scenario of CD is changing to also affecting non-endemic countries, in this review we aimed to describe the spread of $\mathrm{CD}$ cases worldwide from its discovery to its current status as a global public health concern.

\section{DISCOVERY OF CHAGAS DISEASE}

CD was named in honor of its discoverer, Carlos Ribeiro Justiniano Chagas (12), who was born on a coffee farm at Oliveira, Minas Gerais state, in Brazil, on July 9th, 1878 (13). Chagas graduated in Medicine in 1903 and was invited by Oswaldo Cruz to work as a physician at the Ministry of Public Health and Hygiene in Brazil, where he first applied the intra-household vector control against malaria. Due to his success in his work, Chagas became a member of the National Academy of Medicine of Brazil and received several awards and titles from institutions in Paris, Belgium, Lima, and the US, including Doctor Honoris Causa from Harvard University. Besides Chagas was nominated twice for the Nobel Prize in Medicine and Physiology (1913 and 1921), but for unclear reasons, he was never awarded (13). Some evidence points toward political opposition to Chagas in Brazil, due to the socio-economic feature of the disease $(14,15)$. Furthermore, researchers from Europe did not accept this unusual discovery $(15,16)$, and Chagas disease was still not been completely understood by 1912. In 1921, although Chagas had established the principal characteristics of the new disease and published it in a relevant journal of the time, surprisingly there was no written report about the Chagas evaluation in the Nobel Committee of Karolinska Institute, and no scientist received the prize that year $(16,17)$. He headed the Oswaldo Cruz Institute for 17 years (from 1917 until his death in 1934) and coordinated a campaign against the Spanish flu epidemic in Brazil (1918).

On February 14th, 1909, Chagas consulted a patient that would be the first $\mathrm{CD}$ case described in the literature: a 2year-old child, Berenice (Figure 1), who had a high fever, hepatosplenomegaly, face edema and presence of the parasite in the blood (12). Berenice remained asymptomatic throughout her life and died at 73 years from other causes. She was included in several clinical studies of CD from the age of 55 to 71 years old.

Following this, the investigation on CD in Latin America was intensified, with the first reports of the disease in 1913 in El Salvador (18); in 1919 in Peru (19) and in Venezuela (20); in 1922 in Costa Rica (21); in 1924 in Paraguay (21); in 1933 in Guatemala (22); in 1937 in Chile (23); in 1938 in Mexico (24); in 1942 in Bolivia (25); in 1947 in Colombia (26); in 1949 in Nicaragua (21) and in Argentina (27); and 1960 in Honduras (22). More recently, T. cruzi DNA has been found in mummies from Chile/Peru (28) and Brazil, dating from 7,050 years B.C. and 2,500-5,000 years B.C., respectively, demonstrating that the disease has existed in Latin America for more than 9,000 years $(29,30)$ (Figure 2). Despite dating to the pre-Columbian period, CD has not been mentioned before 1909, which makes the findings of Carlos Chagas a unique achievement in the history of parasitology and medicine. He alone described the most important features of a new tropical disease: the vector, the pathogen and its different stages of development, the hosts, as well as its clinical manifestations, epidemiology and even the prophylaxis of the disease.

According to Lannes-Vieira et al. (31), the history of CD can be divided into three important phases. The first from 1909 to 1934 , is characterized by the brilliant work of Chagas and the controversy regarding the definition and legitimation of the disease as a scientific fact and social problem. The second phase, from 1935 to 1960, falls after the death of Chagas when Mazza and Romaña confirmed the acute form of the disease in Argentina and when Evandro Chagas (Chagas' son) and Emmanuel Dias identified the endemic and chronic character of the disease. Finally, the third phase, from 1961 to present day represents a challenge for both the control and the understanding of CD in diverse aspects, in which the implementation of national and international health policies became a constant need.

\section{CHAGAS DISEASE}

Also known as American trypanosomiasis, CD is caused by the protozoan parasite Trypanosoma cruzi. With complex pathophysiology and a dynamic epidemiological profile, CD remains an important public health concern and is an emerging disease in non-endemic countries.

\section{Trypanosoma cruzi and Vector}

T. cruzi is a hemoflagellate intracellular parasite that belongs to the order Kinetoplastida, family Trypanosomatidae (32). It is the causative agent of $\mathrm{CD}$, possessing the capacity to infect any cell, mainly macrophages, fibroblasts and epithelial cells (33). During its life cycle, the parasite evolves through three main forms: amastigotes (proliferative form found inside vertebrate host cells), epimastigotes (proliferative form found in intestine of invertebrate hosts), and trypomastigotes (the infective form originated from amastigotes in vertebrate hosts; and from epimastigotes in the digestive tract of invertebrate hosts) (34).

$\mathrm{CD}$ is a vector-borne disease, being the parasite transmitted by blood-sucking bugs (also known as "kissing-bug") from 


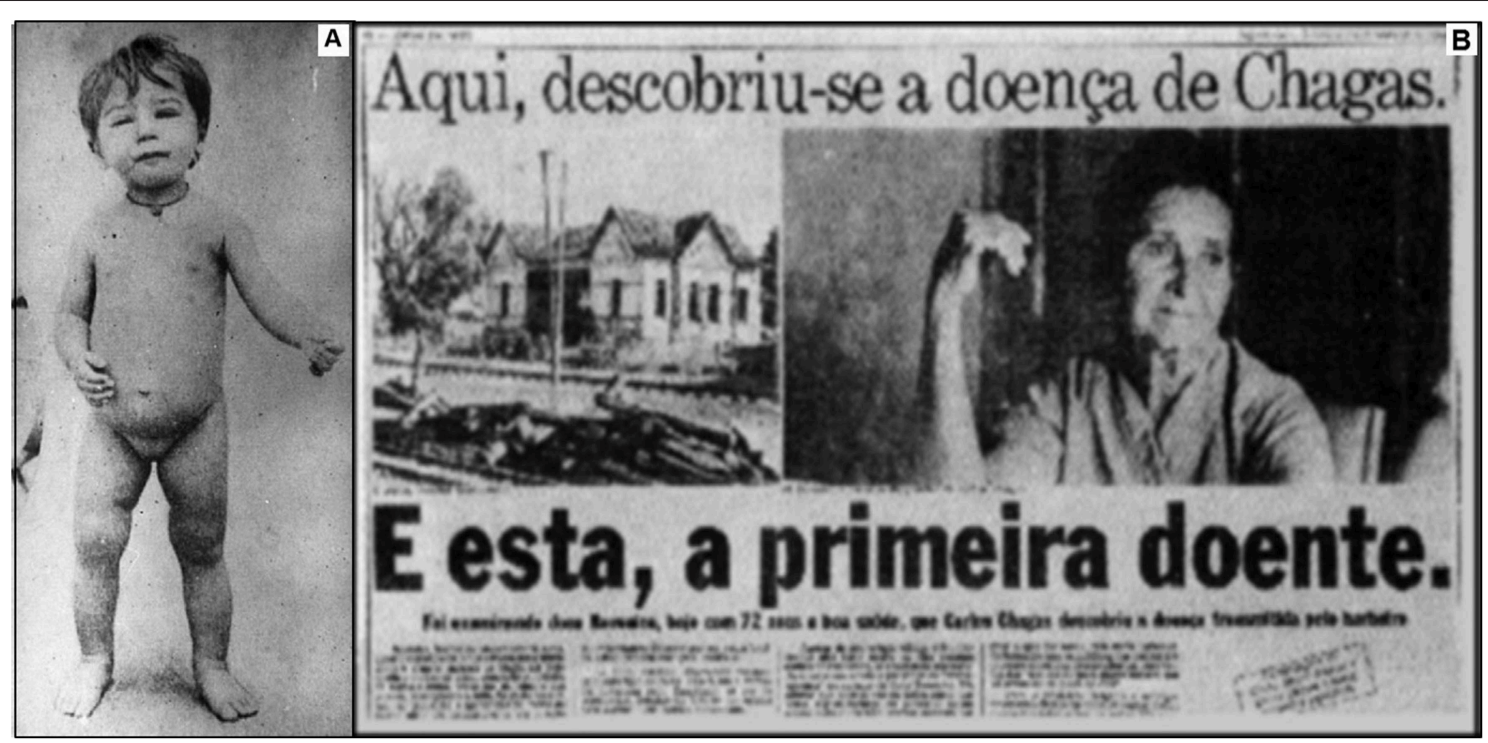

FIGURE 1 | (A) Berenice: the first patient diagnosed with Chagas disease. (B) Brazilian newspaper reporting the history of Chagas disease and Berenice, saying "Chagas disease was discovered here" (up), and: "And this is the first case" (down). Source: Archives of the Instituto Oswaldo Cruz.

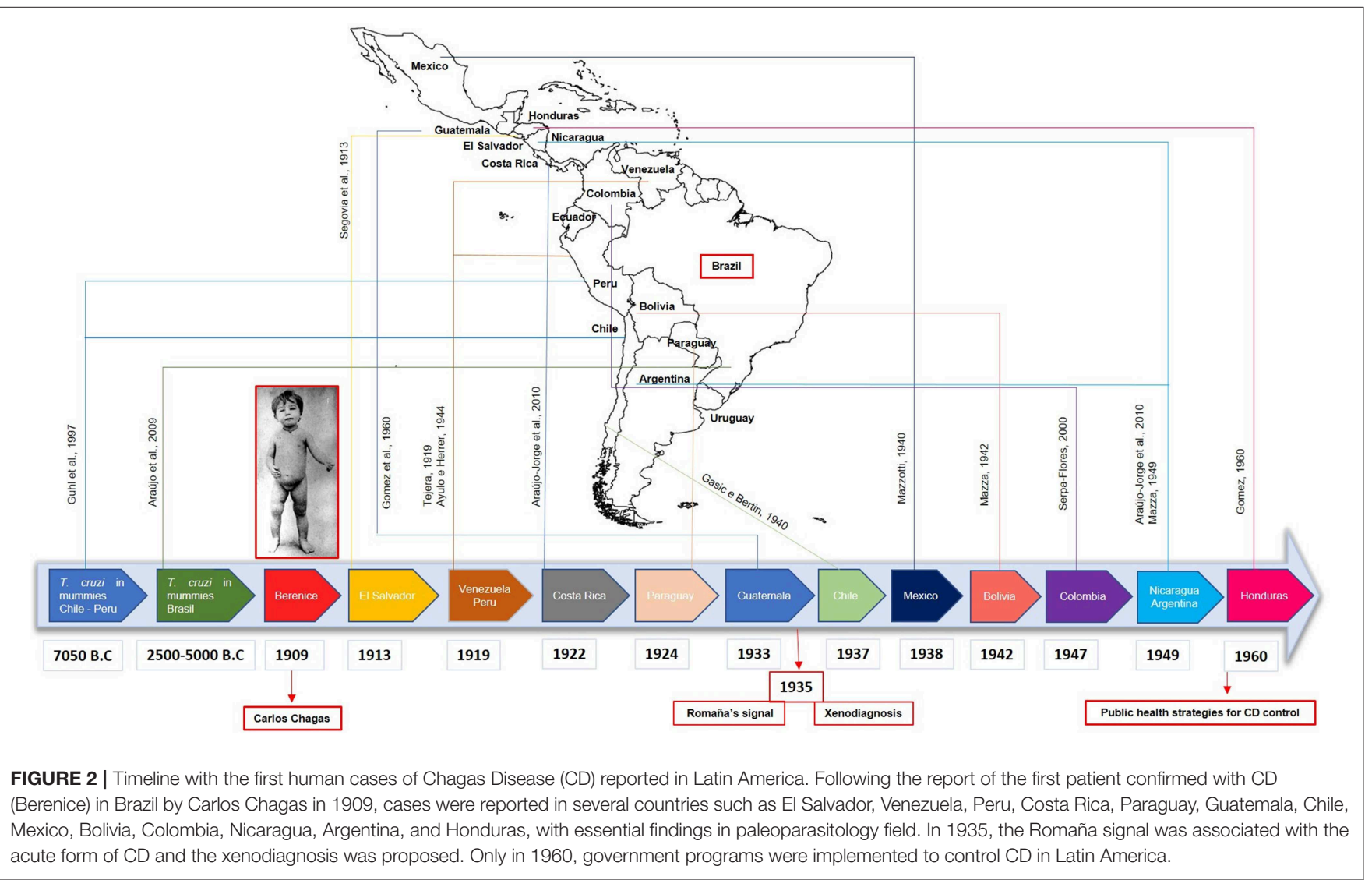

subfamily Triatominiae $(35,36)$. It is known that 140 species of Triatominae are capable of transmitting T. cruzi and are widely distributed in the Americas (37). The most important vectors species are: Triatoma infestans in Argentina, Bolivia, Brazil, Chile, Paraguay, Uruguay and Peru; Rodhinus prolixus in Colombia, Venezuela and Central America; T. dimidiata 
in Ecuador and Central America; and Rhodnius pallescens in Panama (PAHO). In the southern part of USA, the common insect vector is Triatoma gerstaeckeri, followed by T. lecticularia and T. sanguisuga (38).

\section{Transmission Routes}

The vectorial route is considered the classic mode of T. cruzi transmission and the most interesting from an epidemiological point of view, due to its direct connection to social, cultural and economic aspects of a population (39). Interestingly, the endemic area for $\mathrm{CD}$ highly overlaps with the distribution of most bugs from the Triatominae family (40). With this, systematic insect control drastically reduces or even eliminates the disease expansion $(41,42)$. In this sense, several international efforts were done in the last decades and resulted in vectorial control in Central America, Brazil, Uruguay, Chile, Argentina, and Paraguay (42). In the sylvatic cycle, the mammalian reservoirs are mostly primates, rodents, and marsupials. In the domestic cycle, the mammalian reservoirs are humans, dogs, and cats (34).

As there is a considerable flow of migrants from endemic to non-endemic countries, T. cruzi transmission by transfusion of contaminated blood poses a barrier to disease control (43). Transfusion transmission depends on technical parameters in the trial for blood donors as systematic screening for anti- $T$. cruzi antibodies, and intrinsic aspects of donor or receptor as parasite load and immune status, respectively (44). Also, the transmission through infected organs needs to be carefully followed up with, since $T$. cruzi infection may become exacerbated due to the immunosuppressive status of the organ recipient (45).

According to the World Health Organization (3), there are $1,124,930$ women between 15 and 44 years old infected with T. cruzi in Latin America, and the overall risk of congenital T. cruzi infection in children born from infected mothers is around 5\% (46). The success of maternal-fetal transmission depends mainly on parasite genetic variability and maternal-fetal immune responses (43).

The oral transmission route was observed first in animal models in 1913 (47) when it was proposed that reservoirs could acquire the parasite through feeding of contaminated bugs (48). This was later confirmed by experimental infections in a murine model using contaminated blood with trypomastigotes, urine, and feces from contaminated bugs or cultured T. cruzi (49). In humans, oral transmission of T. cruzi has been described as point source outbreaks in which groups of people have shared contaminated food or beverages during an event (50). The first cases of $\mathrm{CD}$ transmitted by oral route were described in Brazil by Silva et al. (51) in Rio Grande do Sul state, and by Shaw et al. (52) in Pará state, and both occurred due to ingestion of a shared meal (50). After the implementation of eradication measures for the vectors and the establishment of routine tests to detect T. cruzi in blood bank trials, the oral route has emerged as an important form of transmission. Additionally, some foodborne cases were reported in regions where triatomine intradomiciliary and peridomestic control has been effective (53).

\section{Clinical Forms}

$\mathrm{CD}$ has complex pathophysiology and a variable clinical presentation. After the primary T. cruzi infection, the acute phase is characterized by a high-grade parasitemia and is, in most cases, asymptomatic. However, symptomatic manifestations of the acute phase- such as prolonged fever, headache, myalgia, lymphadenitis, hepatomegaly, and splenomegaly-usually cease within 60 days even without the use of etiological drugs (54). In the case of vector transmission, the infected individual can present clinical signs resulting from $T$. cruzi inoculation at the portal of entry: chagoma when the entry occurred through the skin or Romañas sign when it occurred through the periorbital mucosa (6). After a period of 4 to 8 weeks, the parasitemia decreases and the clinical manifestations spontaneously disappear in $90 \%$ of the cases, when the disease enters the chronic phase (55).

During the chronic phase, the infection remains clinically silent for life in 60 to $70 \%$ of cases, characterizing the asymptomatic (also known as indeterminate) form of CD (34). Nevertheless, after $10-30$ years, $30-40 \%$ of the asymptomatic patients will develop clinical manifestations, among them neurological (rare), digestive (megacolon and megaesophagus syndromes), cardiac or cardio digestive (7). Cardiac involvement is the most serious manifestation of $\mathrm{CD}$, affecting $1 / 3$ of infected individuals at some point in their lives (8). Chronic chagasic cardiomyopathy (CCC) is characterized by diffuse myocarditis, with tissue substitution by fibrosis and segmental wall motion abnormality (56), with the dilated cardiomyopathy with heart failure being considered the late stage of clinical progression (55). The digestive form of $\mathrm{CD}$ is due to denervation of the enteric nervous system that regulates the motor functions of the digestive tract, which results in dysphagia (57). The hypomotility of the digestive system also leads to a dilatation of the colon with consequent massive constipation $(58,59)$.

Although in many cases, both megacolon and megaesophagus decrease patient's quality of life, when the concomitant development of CCC occurs, characterizing cardiodigestive form, the prognosis is limited (57).

\section{Diagnosis and Treatment}

The diagnosis of human $\mathrm{CD}$ can be performed at any stage of the disease and involves the analysis of clinical, epidemiological, and laboratory data (60). In the acute phase, it is possible to determine the presence of circulating parasites in the peripheral blood by parasitological tests, that can be direct as blood smear or thick blood smear, or by multiplication as hemoculture, xenodiagnoses, and polymerase chain reaction (PCR) (61). In the chronic phase, at least two serological tests based on different principles must be performed to detect anti-T. cruzi IgG antibodies, such as indirect immunofluorescence, hemagglutination, and enzymelinked immunosorbent assay (ELISA). In case of blood trial in blood banks, a single ELISA test is sufficient to decide on blood exclusion (3). In addition to parasitological and serological tests, routine laboratory tests, electrocardiogram (ECG), chest radiography, and hepatogram are requested both in the acute and chronic phases for clinical evaluation (62-64). 
CD treatment involves both parasite-specific and symptomatic treatments (65). The drugs currently in use as antiparasitic therapy in CD, benznidazole and nifurtimox, are effective in the acute cases, in congenital cases, and in reactivation due to immunosuppression; however, treatment is often discontinued due to a required prolonged course and various adverse effects $(5,55,66)$. Although there is no consensus for the use of the treatment in the chronic phase, studies have shown that antiparasitic treatment was able to prevent the onset or delay the progression of CD in the evaluated cases $(62,67)$. On the other hand, in a multi-center study, named BENEFIT (Benznidazole Evaluation for Interrupting Trypanosomiasis), patients with CCC were treated with benznidazole and no delay in the clinical progression was observed for the most severe forms of cardiomyopathy (68). However, the treatment reduced the number of associated clinical intercurrences (69). Recently, a clinical trial (BENDITA) demonstrated that changing treatment protocol duration from 8 weeks to 2 weeks with a daily dose of $300 \mathrm{mg} /$ day of benznidazole was efficient after completing treatment or at the 12-month follow-up (70).

It is important to emphasize that the cure rate and its confirmation depend on factors such as phase and duration of disease, age of the patient, the tests used for the evaluation of therapeutic efficacy and the time of follow-up after treatment, associated comorbidities, and even the susceptibility of the $T$. cruzi genotype to the anti-parasitic drugs used (71).

In general, only symptomatic supportive treatment is performed in CD chronic phase, while patients with CCC are recommended to follow the treatment protocol for heart failure according to cardiac commitment grade (72), being heart transplantation the only course of action in case of advanced heart failure (45). Whereas, to patients with digestive involvement, conservative or even surgical treatment is indicated depending on the stage of the disease (73). Regarding the chronic asymptomatic patients, careful follow-up is indicated, with the use of antiparasitic drug therapy recommended in particular cases, such as childbearing-aged women, where treatment can prevent congenital infection and in some cases the development of heart disease $(66,74)$.

\section{CLASSICAL ENDEMIC AREAS FOR CD}

The ancestral lineages of Trypanosoma cruzi were probably introduced to South America via bats $\sim 7-10$ million years ago (75). The oldest evidence of T. cruzi infection came from the detection of parasite DNA in a 9,000-year-old Chinchorro mummy from the coastal area of Atacama Desert (28). It has been hypothesized that Chinchorro people that used to have a nomadic lifestyle participate in the sylvatic cycle of T. cruzi. Gradually after their settlement, a domestic cycle of $T$. cruzi transmission emerged $(28,76)$, which was facilitated by the ability of the vectors to adapt easily to more opened vegetation (77). Additionally, historical findings suggest that many pre-Hispanic cultures were in close contact with triatomine insect vectors in their dwellings before the arrival of European conquerors to
South America, Central America, and Mexico (28). From the beginning of the Sixteenth century, there is evidence that CD was present in Latin America, affecting indigenous people as well as the European travelers $(78,79)$. Some centuries after, in 1908, during an anti-malaria campaign in support of the construction of a railway track in the state of Minas Gerais (Brazil), a railroad engineer warned Carlos Chagas of large bloodsucking insects which lived in local dwellings and bit sleeping people preferentially in the face (12). Then, Chagas dissected them and found numerous trypanosomes in their hindgut (80). At that time, T. cruzi transmission cycles were restricted to the sylvatic environment, being initially an enzootic phenomenon, but due to rural exodus, deforestation and urbanization, CD became an anthropozoonosis (81).

After its discovery, CD has remained for many decades as an exclusively rural disease associated with social aspects of poverty in areas of Latin America (40). Indeed, CD was always associated with regions presenting severe political deformation, economic instability, illiteracy and miserable huts (82). The classical endemic area of CD ranges from southern region of the USA to the north part of Argentina and Chile, comprising 21 countries (Argentina, Belize, Bolivia, Brazil, Chile, Colombia, Costa Rica, Ecuador, El Salvador, French Guyana, Guatemala, Guyana, Honduras, Mexico, Nicaragua, Panama, Paraguay, Peru, Suriname, Uruguay, and Venezuela) (40). In this area, about 6 million people are affected, occurring approximately and 28,000 new cases of CD and 12,000 deaths per year (4). The Pan American Health Organization (PAHO) estimates that 65 million people live in areas of exposure and are at risk of being infected (Table 1).

The distribution and epidemiological characteristics of CD can change according to environmental factors and degree of human interference in the wild ecotope. Thus, Coura et al. (42) divided $\mathrm{CD}$ in the Americas into four groups based on epidemiological characteristics (the domestic, peridomestic and sylvatic cycle of the parasite) and characteristics of the infection and the disease. The first group includes Venezuela, Peru, Paraguay, Ecuador, Chile, Brazil, Bolivia, and Argentina, where heart disease is predominant, and the wild, peridomestic and domestic cycles are found. In these countries, the parasite transmission by blood transfusion and by T. infestans is under control. In the second group, formed by Costa Rica, Colombia and Mexico, the domestic and peridomestic cycles are found with unsatisfactory vector control. In this group, the prevalent form of CD is the chronic chagasic cardiomyopathy. The third group includes El Salvador, Guatemala, Nicaragua, Panama, and Honduras, and is characterized by the presence of the domestic, peridomestic and wild cycles. The information about clinical forms of $\mathrm{CD}$ in these countries is very limited. In the fourth group, that includes United States of America (USA), Guyana, French Guyana, Haiti, Jamaica, Suriname, Cuba, Belize, and the Bahamas. In these countries, human cases occur mainly among immigrants from endemic areas, where the wild cycle is predominant $(42,83)$.

The assumption of vector controlling as the most effective method for preventing T. cruzi transmission in endemic areas motivated, in 1991, the establishment of the "Southern Cone 
TABLE 1 | Estimated number of infected individuals and people at risk of infection in Latin America from 1980 to 2010.

\begin{tabular}{|c|c|c|c|c|c|c|}
\hline & \multicolumn{2}{|c|}{ 1980-1985 } & \multicolumn{2}{|c|}{2005} & \multicolumn{2}{|c|}{2010} \\
\hline & $\begin{array}{l}\text { Infected } \\
\text { individuals }\end{array}$ & $\begin{array}{l}\text { Individuals at risk of } \\
\text { infection (\%) }\end{array}$ & $\begin{array}{l}\text { Infected } \\
\text { individuals }\end{array}$ & $\begin{array}{l}\text { Individuals at risk of } \\
\text { infection (\%) }\end{array}$ & $\begin{array}{l}\text { Infected } \\
\text { individuals }\end{array}$ & $\begin{array}{l}\text { Individuals at risk of } \\
\text { infection (\%) }\end{array}$ \\
\hline \multicolumn{7}{|l|}{ SOUTHERN CONE } \\
\hline Argentina & $2,640,000$ (10\%) & 23 & $1,600,000(4.1 \%)$ & 23 & 1,505,235 (3.64\%) & 5.42 \\
\hline Bolivia & $1,300,000(24 \%)$ & 32 & $620,000(6.8 \%)$ & 32 & 607,186 (6.1\%) & 5.9 \\
\hline Brazil & $6,180,000(4.2 \%)$ & 32 & 1,900,000 (1\%) & 32 & 1,156,821 (0.6\%) & 13.4 \\
\hline Chile & 1,460,000 (16.9\%) & 63 & $160,200(1 \%)$ & 63 & 119,660 (0.7\%) & 0 \\
\hline Paraguay & 397,000 (21.4\%) & 31 & $150,000(2.5 \%)$ & 31 & 184,669 (2.13\%) & 19.6 \\
\hline Uruguay & $37,000(3.4 \%)$ & 33 & $21,700(0.7 \%)$ & 33 & $7,852(0.23 \%)$ & 0 \\
\hline \multicolumn{7}{|c|}{ ANDEAN INITIATIVE } \\
\hline Colombia & 900,000 (30\%) & 11 & $436,000(1 \%)$ & 11 & 437,960 (0.95\%) & 10.5 \\
\hline Ecuador & 30,000 (10.7\%) & 41 & 230,000 (1.7\%) & 47 & 199,872 (1.38\%) & 28.9 \\
\hline Peru & 621,000 (9.8\%) & 39 & 192,000 (0.7\%) & 12 & 127282 (0.43\%) & 4.5 \\
\hline Venezuela & 1,200,000 (3\%) & 72 & 310,000 (1.2\%) & 18 & 193,339 (0.71\%) & 3.8 \\
\hline \multicolumn{7}{|c|}{ CENTRAL AMERICA } \\
\hline Belize & - & - & $2,000(0.7 \%)$ & 50 & $1,040(0.3 \%)$ & 22.3 \\
\hline Costa Rica & 130,000 (11.7\%) & 45 & $23,000(0.5 \%)$ & 23 & $7,667(0.16 \%)$ & 5.2 \\
\hline El Salvador & 900,000 (20\%) & 45 & 232,000 (3.4\%) & 39 & $90,222(1.3 \%)$ & 15.9 \\
\hline Guatemala & 1,100,000 (16.6\%) & 54 & $250,000(2 \%)$ & 17 & 166,667 (1.2\%) & 10.3 \\
\hline Honduras & 300,000 (15.2\%) & 47 & 220,000 (3.1\%) & 49 & $73,333(9.2 \%)$ & 14.6 \\
\hline NICARAGUA & - & - & $58,600(1.1 \%)$ & 25 & 29,300 (0.52\%) & 11.5 \\
\hline Panama & 200,000 (17.7\%) & 47 & $21,000(0.01 \%)$ & 31 & $18,337(5.2 \%)$ & 13.1 \\
\hline Mexico & - & - & $1,100,000$ (1\%) & 28 & 876,458 (7.8\%) & 20.9 \\
\hline *Guianas/Suriname & - & - & - & - & $12,600(0.8 \%)$ & 25.1 \\
\hline Total & 17,395,000 (4.3\%) & 25 & $7,694,500$ (1.4\%) & 20 & $5,742,167$ (1.1\%) & 12.9 \\
\hline
\end{tabular}

* Guiana and French Guiana. Source: Adapted from (3, 71).

Initiative". This initiative was a multi-country program in the Southern Cone countries (Argentina, Brazil, Bolivia, Brazil, Chile, Paraguay, and Uruguay) which aimed the elimination of Triatoma infestans. In the following years, similar programs were also created in endemic areas as the "Initiative of the Andean Countries" (1997), "Initiative of Central America and Mexico" (1998), and "Initiative of the Amazon Countries" (2004) (35). As a consequence of these programs, a marked decrease was observed in the number of cases transmitted by the vector, which also contributed indirectly to a reduction in the infections via blood transfusion and maternal-fetal route (42). The vectorial and blood transfusion transmissions were declared interrupted in Uruguay in 1997, in Chile in 1999, and in Brazil in 2006, decreasing by $70 \%$ the incidence of T. cruzi in South America (84). However, due to the imbalance caused by environmental and biodiversity changes associated with the presence of human activities close to the sylvatic cycle of $T$. cruzi, the oral transmission has emerged in highly endemic areas such as the Amazon Basin and also in regions where triatomine domestic and peridomestic control has been effective (50). Two foodborne outbreaks occurred in Brazil, one in 2005 in Santa Catarina state (area with vector control), when 24 people were infected after drinking sugarcane juice contaminated with $T$. cruzi (85); and the other in 2006, in Pará state (highly endemic area), with 178 cases of acute disease after eating contaminated açaí fruit (86).

\section{THE NEW SCENARIO OF CHAGAS DISEASE}

While the prevalence of CD in Latin America has been reduced in recent decades, a dramatic increase in the number of CD cases in non-endemic countries have been observed, turning the disease into a worldwide public health concern $(9,87)$.

Human migrations have been indicated as the critical factor for the emergence of $\mathrm{CD}$ in areas where it was not previously described $(87,88)$. In 2017, people born in Latin America and the Caribbean represented the second largest group of international migrants, just behind Asia, with 32 million people living outside their region of birth (89). Of these, the majority was living in Northern America (26 million) and Europe (5 million) (89). The United States are the primary recipients of Latin-American migrants, however, since 2001, when visa regimes to the U.S. became more restricted, Europe is also receiving substantial numbers of immigrants $(90,91)$.

In this context, $\mathrm{CD}$ has already been detected in non-endemic countries from North America (Canada and the U.S.), Europe 
(mainly Spain), and the Western Pacific Region (Australia, New Zealand, and Japan) $(90,92)$ (Figure 3). Currently, around 14\% of the $\$ 7.2$ billion/year estimated global costs with CD (health care and disability-adjusted life-year burden, mainly due to cardiovascular disease) comes from non-endemic countries, and about $12 \%$ of these costs emanate from the U.S. and Canada (10). However, the real significance and public health implications of $\mathrm{CD}$ in this new epidemiological scenario are still unclear.

Several authors estimate the number of CD cases based on the total number of immigrants received by each host country and the T. cruzi prevalence in the country of origin according to the Pan American Health Organization (PAHO) (90, 94, 96-99). On the other hand, results from systematic reviews and metaanalysis seem to indicate more accurate prevalence estimates of CD in non-endemic countries $(88,100)$. Regardless of the estimate employed, the results indicate a growing number of $\mathrm{CD}$ cases in non-endemic countries and therefore the requirement for more attention and efforts toward disease control.

\section{Prevalence in the United States and Canada}

The oldest known case of T. cruzi infection in the U.S. was confirmed in a mummy dated to 1,150 B.P. (29), but the first $\mathrm{CD}$ case in the country was only reported in Texas in 1955 (101). Many southern U.S. states have reported the presence of triatomines, T. cruzi, and infected mammalian hosts. However, only 28 human cases of domestically acquired vector-borne $\mathrm{CD}$ have been confirmed from 1955 to 2015 (102). This low rate of vector-borne transmission might be the result of lower transmission efficiency of North American vectors as well as better housing conditions (97). Thus, the vast majority of CD cases in the U.S. are from immigrants, who acquired T. cruzi in their home countries.

In 2005, it was estimated that more than 22 million people born in CD endemic countries of Latin America were living in the U.S., of which 300,167 were estimated to be infected with T. cruzi (97). Mexico contributed the highest number of immigrants with CD (58\%), followed by El Salvador (16.4\%) and Guatemala (6.8\%). Considering that a proportion of $10-15 \%$ of infections will develop clinical disease, it is expected that $30,000-$ 45,000 of those infected individuals may have undiagnosed Chagas cardiomyopathy (97). A similar study performed in 2007 estimated a higher number of infected immigrants in the U.S., with about 325,671 potentially infected, of which $20 \%$ (65133) have or will have symptoms of CD (93). Inversely, a recent estimate conducted in 2012 indicate a lower prevalence of immigrants with T. cruzi infection in the U.S. (238091). Nevertheless, it does not include undocumented immigrants who may represent about 109,000 additional cases (96). In this study, states with the highest estimated numbers of cases are California (30\%), Texas (16\%), Florida (8\%), and New York (7.3\%) (96).

The number of international migrants worldwide has continued to overgrow. In 2017, the Department of Economic and Social Affairs of the United Nations reported that around 26 million of Latin America and Caribbean migrants were living in Northern America (89). Thus, it is thought that the number of immigrants with $\mathrm{CD}$ living in the U.S. might be even more significant.

A total of 5,553 (3.5\%) of the 156,960 Latin American immigrants living in Canada in 2006 were estimated to be infected with T. cruzi (93). Of these, the vast majority came from Colombia (1,293), followed by Argentina (968) and El Salvador (913). It is expected that about 1,111 of those immigrants may need medical attention due to CD (93).

\section{Prevalence in Europe, Australia, New Zealand, and Japan}

Currently, as well as in the U.S., there is a large number of immigrants living in Europe, with around 5 million people from Latin America (89), most of them in Spain, Italy, France, United Kingdom, and Switzerland (103).

In 2009 , it was estimated that about 68,318 to 123,078 immigrants living in Europe were infected by T. cruzi, the great majority (ca. 48 million) in Spain (104). Bolivia contributed with the highest number of immigrants with CD (56.4\%), followed by Ecuador (11.2\%), and Argentina (10.4\%). Despite this estimate, only 4,290 confirmed cases were reported until 2009 in Europe, meaning that $94-96 \%$ of cases may remain undiagnosed (99). Several other studies estimated the prevalence of CD in Europe, however, results are occasionally quite divergent, mainly due to different sources of the number of Latin American immigrants as well as infection rates $(90,93,103,105-107)$. More recently, a study assembled those estimates arriving between 13,932 and 181,181 cases of CD in Europe with 54,354 immigrants expected to develop CCC (94). Besides that, results from systematic reviews and meta-analysis indicate an underestimation of $\mathrm{CD}$ prevalence in some European countries $(88,100)$. The pooled prevalence of documented cases of $\mathrm{CD}$ in the literature in migrants from Bolivia and Paraguay living in Europe (18 and $5.5 \%$, respectively) was higher compared to PAHO prevalence in the countries of origin ( 6.75 and $2.54 \%$, respectively) which may reflect a higher proportion of migrants from highly endemic areas from Bolivia and Paraguay to Europe. The authors even indicate those estimates to measure the burden of $\mathrm{CD}$ in European countries (100).

Japan is home to more than 370,000 Latin American immigrants, most of them from Brazil (87\%), with an estimated prevalence of over 4,000 cases of T. cruzi infected residents as of 2007 (95). Despite this estimate, only 8 cases of CD have been documented in the period between 1995 and 2015 (95, 108113). In 2011, a total of 116,430 immigrants from CD endemic countries were residing in Australia, 1,928 (2\%) of which had CD. Argentina $(n=550)$, El Salvador $(n=366)$, and Chile $(n$ $=280)$ were the main source countries $(62 \%)$ of immigrants with CD (92). According to an estimation performed in 2006, New Zealand hosted $82 \mathrm{~T}$. cruzi infected residents in a total of 3,615 Latin American immigrants, mostly from Bolivia, Brazil, and Chile (92). 


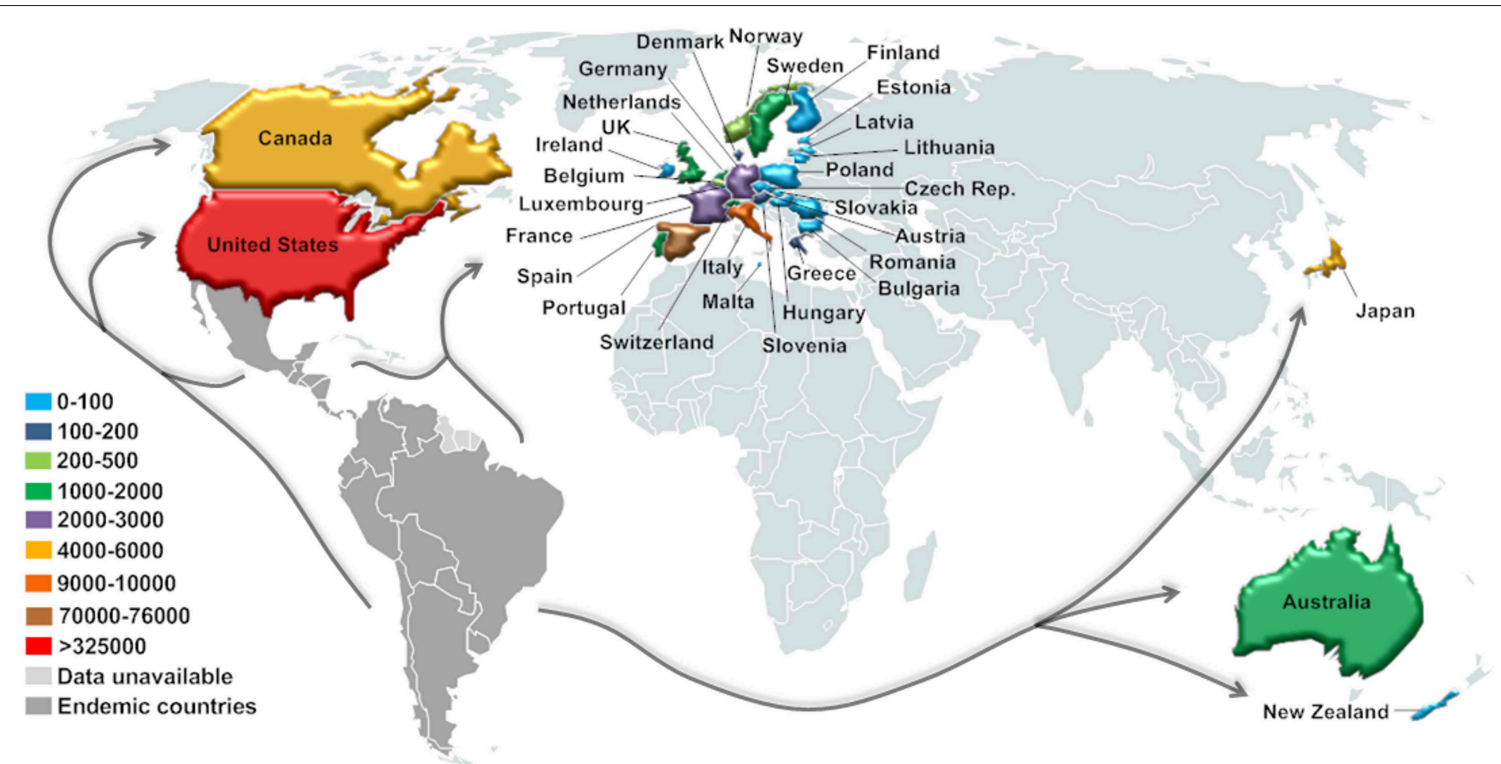

FIGURE 3 | Current estimated number of immigrants with T. cruzi infection in non-endemic countries. Estimation based on data for the United States (2007) and Canada (2006) (93), Europe (2008-2011) (94), Japan (2007) (95), Australia (2011), and New Zealand (2006) (92).

\section{Blood Transfusion, Congenital, and Post-transplant T. cruzi Infection}

In non-endemic countries, $T$. cruzi transmission may occur through blood transfusions and organ transplants from infected donors as well as congenital transmission from mother-to-child during pregnancy. Newly acquired T. cruzi infections by those routes have been reported in non-endemic areas such as U.S, Spain, Switzerland, and, most recently, Japan $(96,103)$.

Widespread screening of blood donations for $T$. cruzi infection was implemented in the U.S. in January 2007 and now covers $75-90 \%$ of the blood supply $(9,114)$. Most centers screen all blood donations; however, a small number perform serological tests only for donations from individuals who reported being at risk (such as those from endemic countries, temporary resident, and/or traveling in endemic areas) (90). Since 2007, the American Association of Blood Banks (AABB) has reported 1,908 confirmed cases of T. cruzi infection identified through screening of blood donations, the majority of them in the states of California (707), Florida (260), and Texas (176) (96). The proportion of blood donors that are infected with $T$. cruzi is higher in cities with large numbers of Latin American immigrants, such as Los Angeles $(1 / 7,500)$ and Miami $(1 / 9,000)(115)$. In Europe, a systematic screening of at-risk blood donations for T. cruzi infection was first implemented in the United Kingdom (1999) followed by Spain (2005), France and Sweden (2009), and more recently in Switzerland (2012), and Belgium (2013) (103). The highest rates of positive serology were observed in Italy (3.9\% of 128 blood donors) (116), Spain $(1.91 \%$ of 1,201$)$ (117), France $(0.31 \%$ of 972$)$ (118), Switzerland ( 0.08 of 1,183 ) (119), United Kingdom (0.007\% of 38.585) (120), while no case was observed in the Netherlands ( $0 \%$ of 1,333$)(121)$. Since 2003 Australia has tested 154 donors at risk of CD, with an estimated risk of T. cruzi transmission of $0.04 \%$ (92). Japan has still not implemented routine test-based screening for donated blood to detect $T$. cruzi infection, although a questionnaire is used to determine the self-reported risk to CD (109).

Mother-to-child transmission is another way of T. cruzi infection that is of concern in non-endemic countries. T. cruzi prevalence in a study performed in 1,350 Latin American pregnant women in Spain was 3.4\%, of which $91 \%$ came from Bolivia (122). In Texas, the U.S., a study performed in a hospital showed that 10 of 4,000 mothers $(0.25 \%)$ presented $T$. cruzi infection; most of the women were from Latin America (123, 124). Annually, the estimate of babies with congenital T. cruzi infection is between 63 and 315 in the U.S. and 20 to 183 in Europe [80, (104)]. Given that at birth most of the infected newborns are asymptomatic or present non-specific CD symptoms such as low birth weight, respiratory distress, and myocarditis, it is believed that the congenital CD is underdiagnosed $(103,125)$. Since newborns usually present high rates of parasitemia, congenital infection can be confirmed by direct observation of $T$. cruzi trypomastigotes under microscopy in samples from the cord or peripheral blood (104). In Japan, around 30 newborns were estimated to be infected in the past decade, however, no country in the Western Pacific region present screening programs for $T$. cruzi infection in pregnant mothers and newborns $(92,109)$.

Organ transplantation has opened another route of $T$. cruzi transmission in non-endemic countries. Five cases of CD after organ transplantation were described in the U.S. $(126,127)$. Moreover, 17 organs being considered for transplantation in the U.S. were discarded due to seropositive test for T. cruzi in 2008 (128). In Spain, T. cruzi transmission by cord blood transplants and bone marrow have been documented (129, 130). Also, 
recently, a case of T. cruzi transmission by liver transplantation was reported in a Spanish woman who received the organ from a Bolivian woman donor (131).

\section{FUTURE IMPLICATIONS}

Although in 2019 marks 110 years since the discovery of $\mathrm{CD}$, it is still one of the most important neglected tropical diseases (132). Moreover, with globalization, CD has become a concern in nonendemic countries (133). Taking that into account, the WHO launched in 2007 the Global Network for Chagas Elimination to coordinate global efforts toward CD elimination. Since then, the WHO has conducted a series of meetings: "Control and prevention of Chagas disease in Europe (2009)," "Informal Consultation on Chagas Disease in the Western Pacific (2011)," and the "World Health Assembling resolution Chagas disease: control and elimination (2010)" (134). The non-endemic countries health politics agreed in contributing to control and to interrupt disease transmission by (i) systematically screening blood for transfusions and organs for transplantation, patients under treatment and newborns infected through congenital transmission; (ii) improving clinical diagnosis and case management; (iii) sharing information about $\mathrm{CD}$, and (iv) training health personnel to facilitate diagnosis and medical care $(133,135)$.

However, the main challenges found to control and treat $\mathrm{CD}$ in non-endemic countries are: funding for healthcare education programs; screening programs for pregnant women and donors (blood and organs); access to healthcare for chronically infected individuals; socioeconomic factors; cultural and language barriers faced by immigrants; as well as the lack of information and trust in government programs for immigrants (133). At the same time endemic countries need to overcome the following challenges against $\mathrm{CD}$ : control the main vectors and other species of triatomine bugs which are able to adapt and substitute the main vectors; and interruption of $T$. cruzi transmission by vectorial, blood transfusion, organ transplantation, congenital, or vertical routes (134). Moreover, a projection of the implications of climatic change for 2050 on the geographical distribution of both Rhodnius prolixus and Triatoma infestans in Venezuela and Argentina suggest that climatic niche approach might contribute to the decreasing trend in the number of new cases of T. cruzi human infections per year (136). Also, information, education, and communication programs on CD still need to be strengthened at the community level (134). Thus, although public health authorities worldwide and in Latin America have made efforts to control the several forms of transmission of $\mathrm{CD}$, there are still many challenges for the elimination of parasites in humans and domestic and wild reservoirs $(134,137)$.

As described before, only two drugs are available for CD treatment: benznidazole or nifurtimox, both of which present serious side effects $(5,138)$. Although Benznidazole, the first treatment approved in the US for CD (139), exists for more than 40 years and is the first-line treatment for CD, only in August 2017 the US Food and Drug Administration (FDA) approved this medication for the treatment of children aged 2-12. Alpern et al. (140) highlighted the excessively priced, and consequently difficult access to drugs for neglected tropical diseases in the US, which might occur with benznidazole once a private company in the US manufactures it. Meanwhile, some clinical trials such as fexinidazole (a new drug candidate), dosing regimens for the treatment of adult patients with $\mathrm{CD}$, optimization of PCR technique to assess parasitological response for patients with chronic $\mathrm{CD}$, population pharmacokinetics study of benznidazole in children with $\mathrm{CD}$ and a proof-ofconcept study of E1224 (a new drug candidate) to treat adult patients with CD are being evaluated (141). Additionally, a wide range of vaccine candidates (including whole parasites, purified or recombinant proteins, viral vectors and DNA vaccines) and immunization approaches have been tested over the years as a preventive and potential therapeutic strategy against CD [as reviewed by Beaumier et al. (142)]. However, up to now no safe and potent vaccine for human utilization is available (143). So, more financial support is required to research new drugs, vaccine candidates, and immunization approaches.

Another critical point of concern is the association of chronic $\mathrm{CD}$ with numerous comorbidities, such as cardiovascular and metabolic diseases, which have been reported in the last decade. Guariento et al. (144) prospectively evaluated 2,497 CD patients and found that $63.8 \%$ had other chronic infirmities, with a higher prevalence $(20.6 \%)$ of systemic arterial hypertension (SAH), followed by diabetes mellitus $(0.4 \%)$. Likewise, Pereira et al. (145) reported that $86.6 \%$ of patients evaluated had at least one comorbidity associated with $T$. cruzi infection, being the major ones SAH (67\%) and dyslipidemia (31.9\%). In addition, Kamiji and De Olivera (146) observed hypertensive heart disease, coronary or valvular disease in $29.5 \%$ of chronic CD patients, while the coexistence of chagasic cardiomyopathy and other heart disease was observed in $26.5 \%$ of patients. The development of cerebrovascular disease associated with SAH (147) and dyslipidemia have also been reported in elderly chagasic patients $(145,147)$. Additionally, necropsies of 92 elderly CD patients revealed SAH (37\%), atherosclerosis (62\%) and ischemic heart disease (6.5\%) (148), indicating an overlap between these comorbidities and CD. Navarro and collaborators (137) reported $75.7 \%$ of dyslipidemia in patients with indeterminate form, suggesting an increased risk of progression to the symptomatic form of $\mathrm{CD}$. Since one of the leading causes of mortality in patients with chronic CD is sudden death, these findings indicate that dyslipidemia and/or atherosclerosis may have a direct influence on patient survival (149). Recently, a metaanalysis demonstrated high mortality for both symptomatic and asymptomatic CD patients when compared to controls. Sudden death, cardiovascular diseases, and heart transplantation were the leading causes of death (150). Thus, more efforts are needed to improve the screening for comorbidities in patients with $\mathrm{CD}$ in order to provide interventions to tackle reversible disorders. Furthermore, CD patients must have an adequate medical follow-up to improve patient's quality of life and avoid a more substantial financial impact on the health system. 


\section{CONCLUSIONS}

In 110 years since its discovery and characterization in Latin America, CD reached a global distribution. Nowadays, CD continues to be a topic of great concern in endemic and nonendemic countries, and the cure or complete eradication of this disease are still some aims to be achieved. Given the current scenario, a multidisciplinary approach is essential to address this challenging disease, in order to achieve better control strategies, development of new diagnostic tools and medications, and investigation and treatment of comorbidities associated with chronic CD.

\section{AUTHOR CONTRIBUTIONS}

$\mathrm{KL}$ and TS participated in the design, coordination, and manuscript writing. FA, LB, FD, and $\mathrm{MB}$ participated in

\section{REFERENCES}

1. Schofield CJ, Jannin J, Salvatella R. The future of Chagas disease control. Trends Parasitol. (2006) 22:583-8. doi: 10.1016/j.pt.2006.09.011

2. Engels D, Savioli L. Reconsidering the underestimated burden caused by neglected tropical diseases. Trends Parasitol. (2006) 22:363-6. doi: $10.1016 /$ j.pt.2006.06.004

3. World Health Organization. Chagas disease in Latin America: an epidemiological update based on 2010 estimates. Wkly Epidemiol Rec. (2015) 90:33-44. Available online at: https://www.who.int/wer/2015/ wer9006.pdf?ua $=1$

4. Pan American Health Organization. Available online at http://www.paho. org/hq/index.php?option=com_content\&view=article\&id=5856\&Itemid= 41506\&lang=en (accessed January 24, 2018) (2016).

5. Pan American Health Organization. Neglected Infectious Diseases in the Americas: Success Stories and Innovation to Reach the Neediest. Pan American Health Organization (2016).

6. Prata A. Clinical and epidemiological aspects of Chagas disease. Lancet Infect Dis. (2001) 1:92-100. doi: 10.1016/S1473-3099(01)00065-2

7. Vago AR, Andrade LO, Leite AA, d'Ávila Reis D, Macedo AM, Adad SJ, et al. Genetic characterization of Trypanosoma cruzi directly from tissues of patients with chronic chagas disease: differential distribution of genetic types into diverse organs. Am J Pathol. (2000) 156:1805-9. doi: 10.1016/S0002-9440(10)65052-3

8. Marin-neto JA, Simões MV, Sarabanda ÁVL. Chagas' heart disease. (1999) 72:247-63. doi: 10.1590/S0066-782X1999000300001

9. Bonney KM. Chagas disease in the 21st century: a public health success or an emerging threat? Parasite. (2014) 21:11. doi: 10.1051/parasite/2014012

10. Lee BY, Bacon KM, Bottazzi ME, Hotez PJ. Global economic burden of Chagas disease: a computational simulation model. Lancet Infect Dis. (2013) 13:342-8. doi: 10.1016/S1473-3099(13)70002-1

11. Abuhab A, Trindade E, Aulicino GB, Fujii S, Bocchi EA, Bacal F. Chagas' cardiomyopathy: the economic burden of an expensive and neglected disease. Int J Cardiol. (2013) 168:2375-80. doi: 10.1016/j.ijcard.2013.01.262

12. Chagas C. Nova tripanozomiaze humana: estudos sobre a morfolojia e o ciclo evolutivo do Schizotrypanum cruzi n. gen, n sp, ajente etiolojico de nova entidade morbida do homem. Mem Inst Oswaldo Cruz. (1909) 1:159-218. doi: 10.1590/S0074-02761909000200008

13. Kropf SP, Sá MR. The discovery of Trypanosoma cruzi and Chagas disease (1908-1909): tropical medicine in Brazil. História Ciências Saúde Manguinhos. (2009) 16:13-34. doi: 10.1590/S0104-59702009000500002

14. Coutinho M, Freire O, Dias JCP. The noble enigma: chagas' nominations for the nobel prize. Mem Do Instit Oswaldo Cruz. (1999) 94:123-9. doi: 10.1590/S0074-02761999000700012 the writing of the manuscript. KL and FA developed the graphic design of figures. IM- $\mathrm{R}$ and TS revised and edited the final manuscript.

\section{FUNDING}

This work was supported by research grants from Fundação Araucária (CP 01/2016 Programa Pesquisa para o Sistema Único de Saúde: Gestão Compartilhada em Saúde - PPSUS Edição 2015 Fundação Araucária- PR/SESA- PR/CNPq/MSDecit). The authors also acknowledge support by Deutsche Forschungsgemeinschaft and Open Access Publishing Fund of University of Tübingen.

\section{ACKNOWLEDGMENTS}

We thank Indira Chakravarti, from Johns Hopkins Bloomberg School of Public Health, for critically reading the manuscript and suggesting substantial improvements.

15. Katz N. The brazilian bibliography on chagas disease : some considerations. Rev Patol Trop. (2016) 45:327-36. Available online at: https://revistas.ufg.br/ iptsp/article/view/43507

16. Bestetti RB. The non-award of the nobel prize of 1921 to carlos chagas: a tragic mistake. J Infect Dis Ther. (2015) 3:3-4. doi: 10.4172/2332-0877.1000220

17. Bestetti RB, Couto LB, Cardinalli-Neto A. When a misperception favors a tragedy: Carlos Chagas and the Nobel Prize of 1921. Int J Cardiol. (2013) 169:327-30. doi: 10.1016/j.ijcard.2013.08.137

18. Segovia JC. Un caso de trypanosomiasis. Arch Hosp Rosales En San Salvador. (1913) 8:249-54.

19. Ayulo VM, Herrer A. Estudios sobre trypanosomiasis americana en el Perú: I. Observaciones en el departamento de Arequipa. Rev Peru Med Exp Salud Publica. (1944) 3:96-117.

20. Tejera E. La trypanosomose americaine ou maladie de Chagas au Venezuela. Bull Soc Pathol Exot. (1919) 12:509-13.

21. de Araujo-Jorge TC, Telleria J, Rios-Dalenz J. History of the discovery of American Trypanosomiasis (Chagas disease). In: Telleira J, Tibayrenc M, editors. American Trypanosomiasis (First Edition). Amsterdam: Elsevier Inc (2010). doi: 10.1016/B978-0-12-384876-5.00001-0

22. León Gómez A, Flores Fiállos A, Reyes Quesada L. Bonilla M, Poujol ER, Gómez C. La Enfermad de Chagas en Honduras. Rev Med Hondureña. (1960) 28:78-83.

23. Gasic G, Bertin V. Epidemiologia de la enfermedad de chagas en Chile. Rev Chil Pediatr. (1940) 11:561-84.

24. Mazzotti L. Dos casos de enfermedad de Chagas en el estado de Oaxaca. Gac Med Mex. (1940) 70:417-20.

25. Mazza S. Consideraciones sobre la enfermedad de Chagas en Bolivia. Prensa Med Arg. (1942) 29:51.

26. Serpa Flórez F. Historia de la Tripanosomiasis Americana en Colombia. Rev Med. (2000) 22:75-7. Available online at: https://revistamedicina.net/ ojsanm/index.php/Medicina/article/view/53-1

27. Mazza S. La enfermedad de chagas em la republica Argentina. Mem Inst Oswaldo Cruz. (1949) 47:273-88. doi: 10.1590/S0074-027619490001 00011

28. Aufderheide AC, Salo W, Madden M, Streitz J, Buikstra J, Guhl F, et al. A 9,000-year record of Chagas' disease. Proc Natl Acad Sci USA. (2004) 101:2034-9. doi: 10.1073/pnas.0307312101

29. Araújo A, Jansen AM, Reinhard K, Ferreira LF. Paleoparasitology of Chagas disease-a review. Mem Do Inst Oswaldo Cruz. (2009) 104: 9-16. doi: 10.1590/S0074-02762009000900004

30. Guhl F, Jaramillo C, Yockteng R, Vallejo GA, Caárdenas-Arroyo F. Trypanosoma cruzi DNA in human mummies. Lancet. (1997) 349:1370. doi: 10.1016/S0140-6736(05)63207-2 
31. Lannes-Vieira J, de Araújo-Jorge TC, de Nazaré Correia Soeiro M, Gadelha P, Corrêa-Oliveira R. The centennial of the discovery of Chagas disease: Facing the current challenges. PLoS Neglect Trop Dis. (2010) 4:4-7. doi: 10.1371/journal.pntd.0000645

32. Levine ND, Corliss JO, Cox FEG, Deroux G, Grain J, Honigberg BM, et al. A newly revised classification of the protozoa. J Protozool. (1980) 27:37-58. doi: 10.1111/j.1550-7408.1980.tb04228.x

33. Lieke T, Steeg C, Graefe SEB, Fleischer B, Jacobs T. Interaction of natural killer cells with Trypanosoma cruzi-infected fibroblasts. Clin Exp Immunol. (2006) 145:357-64. doi: 10.1111/j.1365-2249.2006.03118.x

34. Rassi A, Marin-Neto JA. Chagas disease. Lancet. (2010) 375:1388-402. doi: 10.1016/S0140-6736(10)60061-X

35. Coura JR. Chagas disease: control, elimination and eradication. Is it possible? Mem Instit Oswaldo Cruz. (2013) 108:962-7. doi: 10.1590/0074-0276130565

36. Gourbière S, Dorn P, Tripet F, Dumonteil E. Genetics and evolution of triatomines: from phylogeny to vector control. Heredity. (2012) 108:190-202. doi: 10.1038/hdy.2011.71

37. Schofield CJ, Galvão C. Classification, evolution, and species groups within the Triatominae. Acta Tropica. (2009) 110:88-100. doi: 10.1016/j.actatropica.2009.01.010

38. Garcia MN, O’Day S, Fisher-Hoch S, Gorchakov R, Patino R, Feria Arroyo $\mathrm{TP}$, et al. One health interactions of chagas disease vectors, canid hosts, and human residents along the Texas-Mexico Border. PLoS Negl Trop Dis. (2016) 10:1-10. doi: 10.1371/journal.pntd.0005074

39. Briceño-León R, Galván JM. The social determinants of Chagas disease and the transformations of Latin America. Mem Inst Oswaldo Cruz. (2007) 102:109-12. doi: 10.1590/S0074-02762007005000095

40. Pérez-Molina JA, Molina I. Chagas disease. Lancet. (2017) 391:82-94. doi: 10.1016/S0140-6736(17)31612-4

41. Dias J, Silveira A, Schofield C. The impact of chagas disease control in Latin America - a review. Mem Inst Oswaldo Cruz. (2002) 97:603-12. doi: 10.1590/S0074-02762002000500002

42. Coura JR, Viñas PA, Junqueira ACV. Ecoepidemiology, Short history and control of chagas disease in the endemic countries and the new challenge for non-endemic countries. Memorias Inst Oswaldo Cruz. (2014) 109:856-62. doi: 10.1590/0074-0276140236

43. Carlier Y, Truyens C. Maternal-Fetal Transmission of Trypanosoma cruzi. American Trypanosomiasis Chagas Disease: One Hundred Years of Research: Second Edition, First Edition. Elsevier Inc (2017). doi: 10.1016/B978-0-12-801029-7.00024-1

44. Kun H, Moore A, Mascola L, Steurer F, Lawrence G, Kubak B, et al. Transmission of Trypanosoma cruzi by heart transplantation. Clin Infect Dis. (2009) 48:1534-40. doi: 10.1086/598931

45. Fiorelli AI, Santos RHB, Oliveira JL, Lourenço-Filho DD, Dias RR, Oliveira AS, et al. Heart transplantation in 107 cases of Chagas' disease. Transpl Proc. (2011) 43:220-4. doi: 10.1016/j.transproceed.2010.12.046

46. Howard EJ, Xiong X, Carlier Y, Sosa-Estani S, Buekens P. Frequency of the congenital transmission of Trypanosoma cruzi: a systematic review and metaanalysis. BJOG. (2014) 121:22-33. doi: 10.1111/1471-0528. 12396

47. Brumpt E. Precis de parasitologie. J Parasitol. (1928) 14:277. doi: $10.2307 / 3271390$

48. Dias E. Estudos sobre o Schizotrypanum cruzi. Rio de Janeiro: Universidade de Rio de Janeiro (1933)

49. Mayer H. Infeccion experimental con Trypanosoma cruzi por via digestiva. An Inst Med Region. (1961) 5:43-8.

50. Shikanai-Yasuda MA, Carvalho NB. Oral transmission of chagas disease. Clin Infect Dis. (2012) 54:845-52. doi: 10.1093/cid/cir956

51. Silva NN, Clausell DT, Núbilos H, Mello AL, Ossanai J, Rapone T, et al. Surto epidêmico dc doença de Chagas com provável contaminação oral. Rev Inst Med Trop. (1968) 10:265-76.

52. Shaw J, Lainson R, Fraiha H. Considerações sobre a epidemiologia dos primeiros casos autóctones de doença de Chagas registrados em Belém, Pará, Brasil. Rev Saude Publica. (1969) 3:153-7. doi: 10.1590/s0034-89101969000200005

53. Hontebeyrie M, Brenière SF, Aznar C. Other forms of transmission. In: American Trypanosomiasis, Chagas Disease, One Hundred Years of Research. 1st ed. (2010). p. 583-97. doi: 10.1016/B978-0-12-384876-5.00023-X
54. Barrett MP, Burchmore RJ, Stich A, Lazzari JO, Frasch AC, Cazzulo JJ, et al. The trypanosomiases. Lancet. (2003) 362:1469-80. doi: 10.1016/S0140-6736(03)14694-6

55. Nunes MCP, Dones W, Morillo CA, Encina JJ, Ribeiro AL. Chagas disease: an overview of clinical and epidemiological aspects. J Am College Cardiol. (2013) 62:767-76. doi: 10.1016/j.jacc.2013.05.046

56. Marin-Neto JA, Cunha-Neto E, Maciel BC, Simões MV. Pathogenesis of chronic Chagas heart disease. Circulation. (2007) 115:1109-23. doi: 10.1161/CIRCULATIONAHA.106.624296

57. Matsuda NM, Oliveira RB, Dantas RO, Iazigi N. Effect of isosorbide dinitrate on gastroesophageal reflux in healthy volunteers and patients with Chagas' disease. Dig Dis Sci. (1995) 40:177-82. doi: 10.1007/BF02063962

58. de Oliveira GM, de Melo Medeiros M, da Silva Batista W, Santana R, AraújoJorge TC, de Souza AP. Applicability of the use of charcoal for the evaluation of intestinal motility in a murine model of Trypanosoma cruzi infection. Parasitol Res. (2008) 102:747-50. doi: 10.1007/s00436-007-0829-8

59. Pinazo MJ, Cañas E, Elizalde JI, García M, Gascón J, Gimeno $\mathrm{F}$, et al. Diagnosis, management and treatment of chronic Chagas' gastrointestinal disease in areas where Trypanosoma cruzi infection is not endemic. Gastroenterol Hepatol. (2010) 33:191-200. doi: 10.1016/j.gastrohep.2009.07.009

60. Umezawa ES, Shikanai-Yasuda MA, Stolf AMS. Changes in lsotype composition and antigen recognition of anti- trypanosoma cruzi anti bodies from acute to chronic chagas disease. J Clin Lab Analysis. (1996) 10:407-13. doi: 10.1002/(SICI)1098-2825(1996)10:6<407::AID-JCLA16>3.0.CO;2-0

61. Luquetti AO, Schmuñis GA. Diagnosis of Trypanosoma cruzi infection. In: Telleira J, Tibayrenc $\mathrm{M}$, editors. American Trypanosomiasis Chagas Disease. Amsterdam: Elsevier (2017). p. 687-730. doi: 10.1016/B978-0-12-801029-7.00030-7

62. Bern C, Montgomery SP, Herwaldt BL, Marin-neto JA, Maguire JH, Acquatella $\mathrm{H}$, et al. Evaluation and treatment of chagas disease in the United States a systematic review. JAMA. (2007) 298:2171-81. doi: 10.1001/jama.298.18.2171

63. Lidani KCF, Bavia L, Ambrosio AR, de Messias-Reason IJ. The complement system: a prey of Trypanosoma cruzi. Front Microbiol. (2017) 8:607. doi: $10.3389 /$ fmicb.2017.00607

64. Schijman AG, Bisio M, Orellana L, Sued M, Duffy T, Mejia Jaramillo $\mathrm{AM}$, et al. International study to evaluate PCR methods for detection of Trypanosoma cruzi DNA in blood samples from Chagas disease patients. PLoS Negl Trop Dis. (2011) 5:e931. doi: 10.1371/journal.pntd.0000931

65. Brener Z. Terapêutica experimental na doença de Chagas. In: MB-N, Z Brener, $Z$ Andrade, editors. Trypanosoma cruzi e Doença de Chagas, 2nd edition. Rio de Janeiro: Guanabara Koogan (2000). p. 379-88.

66. Apt W. Treatment of Chagas disease. American Trypanosomiasis Chagas Disease: One Hundred Years of Research: Second Edition (First Edition). Elsevier Inc (2017). doi: 10.1016/B978-0-12-801029-7.00032-0

67. Fabbro DL, Streiger ML, Arias ED, Bizai ML, Del Barco M, Amicone NA. Trypanocide treatment among adults with chronic Chagas disease living in Santa Fe City (Argentina), over a mean follow-up of 21 years: parasitological, serological and clinical evolution. Revista Soc Brasil Med Trop. (2007) 40:110. doi: 10.1590/S0037-86822007000100001

68. Marin-Neto JA, Rassi A, Morillo CA, Avezum A, Connolly SJ, Sosa-Estani $\mathrm{S}$, et al. Rationale and design of a randomized placebo-controlled trial assessing the effects of etiologic treatment in Chagas' cardiomyopathy: the BENznidazole evaluation for interrupting trypanosomiasis (BENEFIT). Am Heart J. (2008) 156:37-43. doi: 10.1016/j.ahj.2008.04.001

69. Morillo CA, Marin-Neto JA, Avezum A, Sosa-Estani S, Rassi A, Rosas F, et al. Randomized trial of benznidazole for chronic chagas' cardiomyopathy. New Engl J Med. (2015) 373:1295-306. doi: 10.1056/NEJMoa1507574

70. DNDi. The BENDITA study: A Phase II Study to Assess Safety, Tolerability, and Efficacy of Different Benznidazole Regimens, Alone and in Combination With Fosravuconazole. Drugs for Neglected Diseases Initiative (DNDi) (2019). Retrieved from https://www.dndi.org/wp-content/uploads/2019/03/ 2page_BenditatStudyOverview_ENG.pdf

71. Dias JCP, Ramos AN, Gontijo ED, Luquetti A, Shikanai-Yasuda MA, Coura JR, et al. [Brazilian Consensus on Chagas Disease, 2015]. Epidemiologia Servicos Saude Revista Sistema Unico Saude Brasil. (2016) 25:7-86. doi: 10.1590/0037-8682-0505-2016 
72. Ribeiro AL, Nunes MP, Teixeira MM, Rocha MOC. Diagnosis and management of Chagas disease and cardiomyopathy. Nat Rev Cardiol. (2012) 9:576-89. doi: 10.1038/nrcardio.2012.109

73. Matsuda NM, Miller SM, Evora PRB. The chronic gastrointestinal manifestations of Chagas disease. Clinics. (2009) 64:1219-24. doi: 10.1590/S1807-59322009001200013

74. Brutus L, Castillo H, Bernal C, Salas NA, Schneider D, Santalla JA, et al. Short report: detectable Trypanosoma cruzi parasitemia during pregnancy and delivery as a risk factor for congenital chagas disease. Am J Trop Med Hygiene. (2010) 83:1044-7. doi: 10.4269/ajtmh.2010.10-0326

75. Hamilton PB, Teixeira MMG, Stevens JR. The evolution of Trypanosoma cruzi: the "bat seeding" hypothesis. Trends Parasitol. (2012) 28:136-41. doi: 10.1016/j.pt.2012.01.006

76. Dias JCP, Schofield CJ. History of Chagas disease as a public health problem in Latin America. In: Teixeira CA, Vinaud M, editors. Emerging Chagas Disease. Sharjah: Bentham Science Publisher (2011). p. 1-9.

77. Walsh JF, Molyneux DH, Birley MH. Deforestation effect of vector-born disease. Parasitology. (1993) 106:S55-75. doi: 10.1017/S0031182000086121

78. Guerra F. American trypanosomiasis. An historical and a human lesson. J Trop Med Hyg. (1970) 72:83-104.

79. Miles MA. The discovery of Chagas disease: progress and prejudice. Infect Dis Clin North Am. (2004) 18:247-60. doi: 10.1016/j.idc.2004.01.005

80. Chagas C. Neue trypanosomen: vorläufige mitteilung. Arch Schiffs Trop Hyg. (1909) 13:120-2.

81. Coura JR. Chagas disease: what is known and what is needed-a background article. Memorias Instit Oswaldo Cruz. (2007) 102:113-22. doi: 10.1590/S0074-02762007000900018

82. Dias J, Schofield C. Social and medical aspects on Chagas disease management and control. In: Telleira J, Tibayrenc M, editors. American Trypanosomiasis Chagas Disease. Amsterdam: Elsevier (2017). p. 47-57. doi: 10.1016/B978-0-12-801029-7.00003-4

83. Coura JR, Dias JCP. Epidemiology, control and surveillance of Chagas disease: 100 years after its discovery. Memórias Instit Oswaldo Cruz. (2009) 104:31-40. doi: 10.1590/S0074-02762009000900006

84. Moncayo A, Silveira A. Current epidemiological trends of Chagas disease in Latin America and future challenges: epidemiology, surveillance, and health policies. In: Enny $\mathrm{T}$, Tibayrenc $\mathrm{M}$, editors. American Trypanosomiasis Chagas Disease, 2nd Edition. Elsevier. (2017) p. 59-88. doi: 10.1016/B978-0-12-801029-7.00004-6

85. Steindel M, Kramer Pacheco L, Scholl D, Soares M, de Moraes MH, Eger I, et al. Characterization of Trypanosoma cruzi isolated from humans, vectors, and animal reservoirs following an outbreak of acute human Chagas disease in Santa Catarina State, Brazil. Diagn Microbiol Infect Dis. (2008) 60:25-32. doi: 10.1016/j.diagmicrobio.2007.07.016

86. Nóbrega AA, Garcia MH, Tatto E, Obara MT, Costa E, Sobel J, et al. Oral transmission of chagas disease by consumption of açaí palm fruit, Brazil. Emerg Infect Dis. (2009) 15:653-5. doi: 10.3201/eid1504.081450

87. Pinazo MJ, Gascon J. The importance of the multidisciplinary approach to deal with the new epidemiological scenario of Chagas disease (global health). Acta Tropica. (2015) 151:16-20. doi: 10.1016/j.actatropica.2015.06.013

88. Conners EE, Vinetc JM, Weeks JR, Brouwer KC. A global systematic review of Chagas disease prevalence among migrants. Acta Trop. (2016) 156:68-78. doi: 10.1016/j.actatropica.2016.01.002

89. United Nations. International Migration Report 2017. United Nations (2017).

90. Gascon J, Bern C, Pinazo MJ. Chagas disease in Spain, the United States and other non-endemic countries. Acta Tropica. (2010) 115:22-7. doi: 10.1016/j.actatropica.2009.07.019

91. Albajar-Viñas P, Jannin J. The hidden chagas disease burden in Europe. Eurosurveillance. (2011) 16:1-3. doi: 10.2807/ese.16.38.19975-en

92. Jackson Y, Pinto A, Pett S. Chagas disease in Australia and New Zealand: risks and needs for public health interventions. Trop Med Int Health. (2014) 19:212-8. doi: 10.1111/tmi.12235

93. Schmunis GA, Yadon ZE. Chagas disease: a Latin American health problem becoming a world health problem. Acta Tropica. (2010) 115:14-21. doi: 10.1016/j.actatropica.2009.11.003

94. Strasen J, Williams T, Ertl G, Zoller T, Stich A, Ritter O. Epidemiology of chagas disease in Europe: many calculations, little knowledge. Clin Res Cardiol. (2014) 103:1-10. doi: 10.1007/s00392-013-0613-y
95. Imai K, Maeda T, Sayama Y, Osa M, Mikita K, Kurane I, et al. Chronic Chagas disease with advanced cardiac complications in Japan: case report and literature review. Parasitol Int. (2015) 64:240-2. doi: 10.1016/j.parint.2015.02.005

96. Manne-Goehler J, Umeh CA, Montgomery SP, Wirtz VJ. Estimating the burden of Chagas disease in the United States. PLoS Negl Trop Dis. (2016) 10:1-7. doi: 10.1371/journal.pntd.0005033

97. Bern C, Montgomery SP. An estimate of the burden of Chagas disease in the United States. Clin Infect Dis. (2009) 49:e52-4. doi: 10.1086/605091

98. Pan American Health Organization. Estimación cuantitativa de la enfermedad de Chagas en las Américas. [Quantitative estimation of Chagas Disease in the Americas]. Report No.: OPS/HDM/CD/425-06. Montevideo: PAHO (2006).

99. Basile L, Jansa JM, Carlier Y, Salamanca DD, Angheben A, Bartoloni A, et al. Chagas disease in European countries: the challenge of a surveillance system. Euro Surveill. (2011) 16:1-10. doi: 10.2807/ese.16.37.19968-en

100. Requena-Méndez A, Aldasoro E, de Lazzari E, Sicuri E, Brown M, Moore DAJ, et al. Prevalence of Chagas disease in Latin-American migrants living in Europe: a systematic review and meta-analysis. PLoS Negl Trop Dis. (2015) 9:1-15. doi: 10.1371/journal.pntd.0003540

101. Hotez PJ, Dumonteil E, Betancourt Cravioto M, Bottazzi ME, TapiaConyer R, Meymandi S, et al. An unfolding tragedy of Chagas disease in North America. PLoS Negl Trop Dis. (2013) 7:5-8. doi: 10.1371/journal.pntd.0002300

102. Montgomery SP, Parise ME, Dotson EM, Bialek SR. What do we know about chagas disease in the United States? Am J Trop Med Hygiene. (2016) 95:1225-7. doi: 10.4269/ajtmh.16-0213

103. Antinori S, Galimberti L, Bianco R, Grande R, Galli M, Corbellino M. Chagas disease in Europe: a review for the internist in the globalized world. Eur J Int Med. (2017) 43:6-15. doi: 10.1016/j.ejim.2017.05.001

104. Basile L, Oliveira I, Ciruela P, Plasencia A, Working Group For Developing The Catalonian Screening Programme for Congenital Transmission of Chagas Disease. The current screening programme for congenital transmission of Chagas disease in Catalonia, Spain. Euro Surveill. (2011) 22:19972. doi: 10.2807/ese.16.38.19972-en

105. Guerri-Guttenberg RA, Grana DR, Ambrosio G, Milei J. Chagas cardiomyopathy: Europe is not spared! Eur Heart J. (2008) 29:2587-91. doi: 10.1093/eurheartj/ehn424

106. Angheben A, Anselmi M, Gobbi F, Marocco S, Monteiro G, Buonfrate $\mathrm{D}$, et al. Chagas disease in Italy: breaking an epidemiological silence. Eurosurveillance. 16:1. doi: 10.2807/ese.16.37.19969-en

107. Bart A, Hodiamont CJ, Grobusch MP, Van Den Brink RBA, Smout En JPM, Van Gool T. De ziekte van Chagas in Nederland EEN SCHaTTING vaN HET aaNTal paTIëNTEN. Ned Tijdschr Geneeskd. (2011) 155:1-6. Retrieved from https://www.ntvg.nl/system/files/publications/a3170.pdf

108. Araki T, Miki C, Yoshiyama S, Toiyama Y, Sakamoto N, Kusunoki M. Total proctocolectomy and ileal J-pouch anal anastomosis for chagasic megacolon with fecaloma: report of a case. Surg Today. (2006) 36:277-9. doi: 10.1007/s00595-005-3140-2

109. Imai K, Maeda T, Sayama Y, Mikita K, Fujikura Y, Misawa K, et al. Motherto-child transmission of congenital chagas disease, Japan. Emerg Infect Dis. (2014) 20:146-8. doi: 10.3201/eid2001.131071

110. Nishimura A, Ueno Y, Fujiwara S, Nushida H, Tatsuno Y. An autopsy case of sudden death due to Chagas' disease. Nihon Hoigaku Zasshi. (1997) 51:39-43.

111. Satoh F, Tachibana H, Hasegawa I, Osawa M. Sudden death caused by chronic Chagas disease in a non-endemic country: autopsy report. Pathol Int. (2010) 60:235-40. doi: 10.1111/j.1440-1827.2009.0 2503.x

112. Takeno M, Seto S, Kawahara F, Yamachika S, Yano K, Tsuda N, et al. Chronic Chagas' heart disease in a Japanese-Brazilian traveler. A case report. Jpn Heart J. (1999) 40:375-82. doi: 10.1536/jhj. 40.375

113. Ueno Y, Nakamura Y, Tahahasi M, Inoue T, Endo S, Kinoshita M, et al. A highly suspected case of chronic Chagas' heart disease diagnosed in Japan. Jpn Circ J. (1995) 59:219-23. doi: 10.1253/jcj.59.219

114. Bern C, Montgomery SP, Katz L, Caglioti S, Stramer SL. Chagas disease and the US blood supply. Curr Opin Infect Dis. (2008) 21:476-82. doi: 10.1097/QCO.0b013e32830ef5b6 
115. Leiby DA, Herron RM, Read EJ, Lenes BA, Stumpf RJ. Implications for transfusion transmission. Transfusion. (2002) 42:549-55. doi: 10.1046/j.1537-2995.2002.00077.x

116. Gabrielli S, Girelli G, Vaia F, Santonicola M, Fakeri A, Cancrini G. Surveillance of Chagas disease among at-risk blood donors in Italy: preliminary results from Umberto I Polyclinic in Rome. Blood Transfusion. (2013) 11:558-62. doi: 10.2450/2013.0055-13

117. Piron M, Vergés M, Muñoz J, Casamitjana N, Sanz S, Maymó RM, et al. Seroprevalence of Trypanosoma cruzi infection in at-risk blood donors in Catalonia (Spain). Transfusion. (2008) 48:1862-8. doi: 10.1111/j.1537-2995.2008.01789.x

118. El Ghouzzi MH, Boiret E, Wind F, Brochard C, Fittere S, Paris L, et al. Testing blood donors for Chagas disease in the Paris area, France: First results after 18 months of screening. Transfusion. (2010) 50:575-83. doi: 10.1111/j.1537-2995.2009.02476.x

119. Ries J, Komarek A, Gottschalk J, Brand B, Amsler L, Jutzi M, et al. A case of possible chagas transmission by blood transfusion in Switzerland. Transfusion Med Hemother. (2016) 43:415-7. doi: 10.1159/000446264

120. Kitchen AD, Hewitt PE, Chiodini PL. The early implementation of Trypanosoma cruzi antibody screening of donors and donations within England: preempting a problem. Transfusion. (2012) 52:1931-9. doi: 10.1111/j.1537-2995.2012.03599.x

121. Slot E, Hogema BM, Molier M, Bart A, Zaaijer HL. Risk factors and screening for trypanosoma cruzi infection of Dutch blood donors. PLoS ONE. (2016) 11:e0151038. doi: 10.1371/journal.pone.0151038

122. Muñoz J, Prat JGi, Gállego M, Gimeno F, Treviño B, López-Chejade P, et al. Clinical profile of Trypanosoma cruzi infection in a non-endemic setting: immigration and Chagas disease in Barcelona (Spain). Acta Tropica. (2009) 111:51-5. doi: 10.1016/j.actatropica.2009.02.005

123. Hotez PJ, Dumonteil E, Woc-Colburn L, Serpa JA, Bezek S, Edwards MS, et al. Chagas disease: "the new HIV/AIDS of the Americas." PLoS Negl Trop Dis. (2012) 6:4-7. doi: 10.1371/journal.pntd.0001498

124. Edwards MS, Rench MA, Todd CW. Perinatal screening for Chagas disease in Southern Texas. J Pediatr Infect Dis Soc. (2015) 4:67-70. doi: 10.1093/jpids/pit056

125. Montgomery SP, Starr MC, Cantey PT, Edwards MS, Meymandi SK. Neglected parasitic infections in the United States: Chagas disease. Am J Trop Med Hygiene. (2014) 90:814-8. doi: 10.4269/ajtmh.13-0726

126. Centers for Disease Control and Prevention. Chagas disease after organ transplantation - United States, 2001. Morb Mort Wkly Rep. (2002) 51:2102. Available online at: https://www.cdc.gov/mmwr/preview/mmwrhtml/ mm5110a3.htm

127. Centers for Disease Control and Prevention. Chagas disease after organ transplantation - Los Angeles, California, 2006. Morb Mort Wkly Rep. (2006) 55:798-800. Available online at: https://www.cdc.gov/mmwr/ preview/mmwrhtml/mm5529a3.htm

128. Schwartz BS, Paster M, Ison MG, Chin-Hong PV. Organ donor screening practices for trypanosoma cruzi infection among US organ procurement organizations. Am J Transplant. (2011) 11:848-51. doi: 10.1111/j.1600-6143.2011.0 3436. $\mathrm{x}$

129. Forés R, Sanjuán I, Portero F, Ruiz E, Regidor C, López-Vélez R, et al. Chagas disease in a recipient of cord blood transplantation. Bone Marrow Transplant. (2007) 39:127-8. doi: 10.1038/sj.bmt.17 05551

130. Villalba R, Fornes G, Alvarez MA, Roman J, Rubio V, Fernandez M, et al. Acute Chagas disease in a recipient of a bone marrow transplant in Spain: case report. Clin Infect Dis. (1992) 14:594-5. doi: 10.1093/clinids/14.2.594

131. Rodriguez-Guardado A, González ML, Rodriguez M, Flores-Chavez M, Boga JA, Gascon J. Trypanosoma cruzi infection in a Spanish liver transplant recipient. Clin Microbiol Infect. (2015) 21:687.e1-3. doi: 10.1016/j.cmi.2015. 03.022

132. Hotez PJ, Alvarado M, Basáñez M-G, Bolliger I, Bourne R, Boussinesq $\mathrm{M}$, et al. The global burden of disease study 2010: interpretation and implications for the neglected tropical diseases. PLoS Negl Trop Dis. (2014) 8:e2865. doi: 10.1371/journal.pntd.0002865

133. Klein N, Hurwitz I, Durvasula R. Globalization of Chagas disease: a growing concern in nonendemic countries. Epidemiol Res Int. (2012) 2012:1-13. doi: $10.1155 / 2012 / 136793$
134. Liu Q, Zhou X-N. Preventing the transmission of American trypanosomiasis and its spread into non-endemic countries. Infect Dis Poverty. (2015) 4:60. doi: 10.1186/s40249-015-0092-7

135. Requena-Mendez A, Albajar-Viñas P, Angheben A, Chiodini P, Gascón J, Muñoz J. Health policies to control Chagas disease transmission in European countries. PLoS Negl Trop Dis. (2014) 8:e3245. doi: 10.1371/journal.pntd.0003245

136. Medone P, Ceccarelli S, Parham PE, Figuera A, Rabinovich JE. The impact of climate change on the geographical distribution of two vectors of Chagas disease: implications for the force of infection. Philos Trans R Soc B Biol Sci. (2015) 370:20130560. doi: 10.1098/rstb.2013.0560

137. Navarro EC, Pereira PCM. Impact of Chagas disease on human evolution: the challenges continue. Adv Anthropol. (2013) 3:1-6. doi: 10.4236/aa.2013.34A001

138. Centers for Disease Control and Prevention. Available online at https://www. cdc.gov/parasites/chagas/health_professionals/tx.html (accessed January 13, 2018) (2017).

139. Word Health Organization. Available online at: http://www.who.int/ neglected_diseases/news/who_facilitate_access_paediatric_treatment/en/ (accessed February 5, 2018) (2017).

140. Alpern JD, Lopez-Velez R, Stauffer WM. Access to benznidazole for Chagas disease in the United States-Cautious optimism? PLoS Negl Trop Dis. (2017) 11:10-4. doi: 10.1371/journal.pntd.0005794

141. DNDi. Drugs for Neglected Disease Initiative. Chagas Disease. (2016). Available online at https://www.dndi.org/2016/clinical-trials/clinical-trialschagas (accessed February 20, 2018).

142. Beaumier CM, Gillespie PM, Strych U, Hayward T, Hotez PJ, Bottazzi ME. Status of vaccine research and development of vaccines for Chagas disease. Vaccine. (2016) 34:2996-3000. doi: 10.1016/j.vaccine.2016.03.074

143. Padilla A, Brandan C, Basombrío M. Vaccine development for Chagas disease. In: Telleira J, Tibayrenc M, editors. American Trypanosomiasis Chagas Disease. Amsterdam: Elsevier (2017). p. 773-96. doi: 10.1016/B978-0-12-801029-7.00033-2

144. Guariento ME, Alliegro FC, De Almeida EA. Doença de Chagas associada a doenças crônicas em pacientes assistidos em ambulatório de hospital universitário*. Rev Bras Clin Med. (2009) 7:84-8. Available online at: http:// www.sbcm.org.br/revistas/RBCM/RBCM-2009-02.pdf\#page $=15$

145. Pereira L, Freitas E, Fidalgo A, Andrade M, Cândido D, Silva Filho J, et al. Clinical and epidemiological profile of elderly patients with Chagas disease followed between 2005-2013 by pharmaceutical care service in Ceará State, Northeastern Brazil. Rev Inst Med Trop. (2015) 57:145-52. doi: 10.1590/S0036-46652015000200008

146. Kamiji MM, De Oliveira RB. O perfil dos portadores de doença de Chagas, com ênfase na forma digestiva, em hospital terciário de Ribeirão Preto, SP. Rev Soc Brasil Med Trop. (2005) 38:305-9. doi: 10.1590/S0037-86822005000400005

147. Alves RMde A, Thomaz RP, de Almeida EA, da Wanderley JS, Guariento ME. Chagas' disease and ageing: the coexistence of other chronic diseases with Chagas' disease in elderly patients. Rev Soc Brasil Med Tropical. (2009) 42:622-8. doi: 10.1590/S0037-86822009000600002

148. Oliveira FA, Reis MA, Teixeira PA. A cardiopatia chagásica em idosos necropsiados. Rev Soc Bras Med Trop. (2001) 34:161-2.

149. Rassi A Jr, Rassi SG, Rassi A. Sudden Death in Chagas' Disease. Arq Bras Cardiol. (2001) 76:86-96. doi: 10.1590/S0066-782X2001000100008

150. Cucunubá ZM, Okuwoga O, Basáñez M-G, Nouvellet P. Increased mortality attributed to Chagas disease: a systematic review and meta-analysis. Parasit Vectors. (2016) 9:42. doi: 10.1186/s13071-016-1315-x

Conflict of Interest Statement: The authors declare that the research was conducted in the absence of any commercial or financial relationships that could be construed as a potential conflict of interest.

Copyright (C) 2019 Lidani, Andrade, Bavia, Damasceno, Beltrame, Messias-Reason and Sandri. This is an open-access article distributed under the terms of the Creative Commons Attribution License (CC BY). The use, distribution or reproduction in other forums is permitted, provided the original author(s) and the copyright owner(s) are credited and that the original publication in this journal is cited, in accordance with accepted academic practice. No use, distribution or reproduction is permitted which does not comply with these terms. 